\title{
Surveillance for Mosquito-borne Viruses 1
}

\section{Roxanne Rutledge ${ }^{2}$}

\section{Mosquitoes and Disease Transmission in Florida}

There are three very important mosquito-borne diseases that occur in Florida: Eastern equine encephalitis, St. Louis encephalitis, and West Nile fever/encephalitis; all of these diseases are caused by viruses that are transmitted by the bite of an infected mosquito.

Adult female mosquitoes feed on blood for the nutrients it provides for developing the eggs that they will deposit. When mosquitoes feed on blood, they salivate prior to and during feeding. If the mosquito feeds on a bird that is infected with one of the viruses, there is a chance that she will pick up the virus from the bird's blood. After a couple of weeks, if the virus has survived in the mosquito and increased to high numbers, she is able to infect a new blood host, such as another bird, a human, or a horse. The virus is released through the saliva when she is feeding. If the virus infects a human or horse, for example, there is a possibility that the new host will develop symptoms of encephalitis and become ill; more often, however, these hosts are only slightly ill or experience no symptoms at all and develop antibodies to the virus. Some birds can harbor the viruses with no ill effects. However, West Nile virus has been fatal to many raptors and corvids (blue jays, crows, hawks).

\section{Mosquito Control in Florida}

Since the early 1900 's, mosquito control districts have been operating in Florida to protect the public from mosquito-borne diseases and pest mosquitoes. In 2003, there were over 50 organized mosquito control districts in Florida. A very important component of any mosquito control program is surveillance.

An integrated surveillance program should monitor weather, mosquito abundance, host abundance, virus activity, human cases of mosquito-borne diseases, and other factors to detect or predict changes in the transmission dynamics of mosquito-borne viruses (CDC 1993). This document considers the monitoring of virus activity, that is, surveillance for the organisms which mosquitoes can transmit from one host (e.g. bird) to another (e.g. human).

\section{Tools for Surveillance}

There are several tools that have been developed for monitoring mosquito-borne viruses. Some tools

1. This document is Fact Sheet ENY-699 one of a series of the Entomology and Nematology Department, Florida Cooperative Extension Service, Institute of Food and Agricultural Sciences, University of Florida. Date first published: March 2004. Please visit the EDIS Web site at http://edis.ufl.edu

2. C. Roxanne Rutledge, assistant professor, Entomology and Nematology Department, Florida Medical Entomology Laboratory, Cooperative Extension Service, Institute of Food and Agricultural Sciences, University of Florida, Vero Beach, FL 32962 
incorporate mosquitoes, while others make use of hosts such as birds, horses, and humans. The following is a description of the tools available to a mosquito control district or health department for mosquito-borne virus surveillance. Table 1 lists the advantages and disadvantages for each tool from a mosquito control operation perspective.

\section{Monitoring of Sentinel Chickens}

Chicken flocks are placed in strategic, secure locations, where they are exposed to biting mosquitoes. Blood samples are taken weekly and are shipped to the State Department of Health testing lab. The animals are maintained in one location and bled on a regular schedule. Part of the test results are returned in one week; the second portion is returned in two weeks. The sampling is active, since it is not dependent on reporting by others, and does not rely on chance reports from the public. A positive chicken is proof of current, local transmission and a narrow window of time of infection can be calculated.

\section{Horse Surveillance}

A horse becomes ill and is reported to a veterinarian. The veterinarian takes blood or tissue samples from the horse and submits them to the Florida Department of Health and the National Veterinary Services Laboratory in Ames, Iowa for testing. The sampling is passive since it is dependent on sick horses being reported to veterinarians and then to the Florida Department of Agriculture, Animal Industry. It can be $4-6$ weeks before mosquito control personnel are informed of a positive horse. If a positive horse was not recently relocated, then local, recent transmission is indicated.

\section{Mosquito Testing}

Mosquitoes are collected, sorted, identified to species, and frozen. The mosquitoes must be kept alive until frozen. Testing is performed on groups containing 1 - 50 females per sample, otherwise known as a "mosquito pool." Once they are ready to be tested, or shipped to a lab to be tested, they must be maintained at -20 degrees Celcius.

Polymerase chain reaction (PCR) and/or virus isolation tests are conducted to look for evidence of exposure to the virus of interest. Neither of these tests will reveal if the mosquito(es) can transmit the virus; tests can only show that the mosquito has come into contact with some level of virus or virus remnants in the past. The sampling effort for this testing requires a large time investment just to collect and identify the mosquitoes. During non-epidemic periods, there are very few infected mosquitoes in any given population. It then requires very large samples containing large numbers of mosquitoes to detect the few infected mosquitoes.

\section{Wild Bird Serum Survey}

Local populations of wild birds are repeatedly sampled to test for antibodies or virus. Adult and immature birds are captured and banded; a blood sample is taken and the bird is released for recapture later. An intensive sampling effort is required because recapture rates are usually very low. Additionally, the technique is expensive and requires trained personnel and bird collecting permits. Antibodies can persist in the birds for 2 years or longer, so a positive adult bird does not necessarily mean it was recently infected. Nestling birds that are seropositive, or virus positive, provide information on more recent infections.

\section{*Dead Bird Reporting}

A bird dies and is located by a citizen, a mosquito control district, or health department employee, and reports this to the local health department. The health department may or may not pick up or accept delivery of the dead bird. Whether or not the bird can be tested depends on the condition of the bird (how fresh it is). If a bird tests positive for West Nile virus or West Nile virus antibody, it means the bird was infected with the virus sometime in the past and died at a particular location. This testing can not reveal where or when the bird was infected. This surveillance method is a passive one that depends on the public to find and report the bird. The effect of different efforts in reporting birds is never known and the time to receive results is weeks or longer. This method does not provide proof of local transmission. 
*The use of dead birds in mosquito-borne disease surveillance is a new technique. Prior to 1999, there was no mosquito-borne virus in the U.S. that caused mortality in birds in such high numbers as West Nile virus. Since the introduction of West Nile into the United States, many states have been testing dead birds for the presence of the virus.

\section{Human Case Reports}

Human cases of mosquito-borne encephalitis are often the only indication of virus circulating in a given area, in particular, in those counties where no other means of surveillance is conducted. This is a passive surveillance method that awaits the appearance of sick humans. A month or more may pass after the case occurs before local mosquito control districts are informed about human cases; and to protect the privacy of the patient, their address or activities are usually not released to the mosquito control personnel. This method of surveillance is the least effective as operational decisions in mosquito control are thwarted by the delay in reporting. By the time the case is reported, the infected mosquitoes are likely gone.

\section{Considerations for Surveillance Tools}

Prior to deciding which tool(s) will be a part of a surveillance program for mosquito-borne viruses, the following questions should be considered:

1. Will the technique provide denominator data useful to assess risk?

For example, with a sentinel chicken flock of known size, we can determine the percent of susceptible chickens infected in a given time period; $1 / 6=17 \%$; or $5 / 6=83 \%$. These numbers can then be compared to historical percentages from that site or from other sites.

Denominator data for wild bird monitoring is difficult to achieve. It is impossible to know the number of susceptible wild birds in a non-captive population.

2. What is the extent of the sampling effort?
How many people will be required to collect data? How much time will it take? Is it easy or difficult to take data?

3. What is the time from collecting data to obtaining results?

If the results will be used to assist in operational decisions, a short time is needed from data collection to obtaining results. Results that take $4-6$ weeks after data collection will not provide timely information for operational control decisions.

4. What will the results mean? Will the results provide usable information?

If the results do not provide meaningful information, time and labor are being wasted. For example, if a PCR test conducted on a mosquito comes back positive, it does not mean that the particular mosquito(es) could transmit the virus. A PCR positive mosquito does not mean the mosquito is important in virus transmission or a danger to humans or animals.

\section{Are historical comparisons available?}

It is important that surveillance programs be long term and include record keeping for historical purposes. If a sentinel chicken flock shows a $30 \%$ seroconversion (development of antibodies in response to infection with one of the viruses) rate at a given site, what is the comparison for previous years, and long-term averages, at that same site? This kind of comparison is a critical component of surveillance to help separate background, "expected" levels from those that are above average.

\section{How will the data be used?}

How the data will be used should be decided at the beginning of the program. If the data will be used to make decisions on when to spray adulticides, when to treat with larvicides, or when to halt control measures, then one must consider the questions above (1-5) to determine if the tools used can provide the information in a timely manner. 


\section{Surveillance Goals}

Mosquito-borne virus surveillance programs should include very specific goals that support the questions being asked by the mosquito control workers. No matter what tool is used, the program should be well planned, long term, include baseline and historical data sets, and produce meaningful results. It isn't just a matter of generating numbers, it is imperative that those running the surveillance programs know what they are looking for, why they are looking for it, and what it will mean when they find it.

\section{References}

CDC. 1993. Guidelines for Arbovirus Surveillance in the United States. U. S. Department of Health and Human Services. Fort Collins, CO. 83 pp.

Day, J. F. and A. L. Lewis. 1991. An Integrated Approach to Arboviral Surveillance in Indian River County, Florida. J. Florida Mosq. Control Assoc. 62(2): 46-52. 
Table 1. Advantages and disadvantages of each surveillance tool from a mosquito control operation perspective.

\begin{tabular}{|c|c|c|c|c|c|}
\hline & $\begin{array}{l}\text { Denominator } \\
\text { data }\end{array}$ & $\begin{array}{l}\text { Samplng } \\
\text { effort } \\
\text { required }\end{array}$ & $\begin{array}{l}\text { Turnaround } \\
\text { time for results }\end{array}$ & $\begin{array}{l}\text { What do results } \\
\text { mean? }\end{array}$ & $\begin{array}{l}\text { Can historical } \\
\text { comparisons be } \\
\text { made? }\end{array}$ \\
\hline $\begin{array}{l}\text { Sentinel } \\
\text { Chickens }\end{array}$ & YES & $\begin{array}{l}\text { Limited in an } \\
\text { established } \\
\text { program }\end{array}$ & 1-2 weeks & $\begin{array}{l}\text { Recent, Local } \\
\text { transmission }\end{array}$ & YES \\
\hline Horses & YES & Passive & 4-6 weeks & $\begin{array}{l}\text { Recent, local } \\
\text { transmission if horse } \\
\text { has not been } \\
\text { recently relocated }\end{array}$ & YES \\
\hline Mosquitoes & YES & Extensive & $\begin{array}{l}6 \text { weeks or } \\
\text { longer (low } \\
\text { priority) }\end{array}$ & $\begin{array}{l}\text { Nothing in terms of } \\
\text { transmission or } \\
\text { implicating } \\
\text { arevector; virus likely } \\
\text { present in area }\end{array}$ & YES \\
\hline Wild Birds & YES & $\begin{array}{l}\text { Extensive } \\
\text { (permits } \\
\text { required) }\end{array}$ & $\begin{array}{l}\text { Sear=1 week; } \\
\text { blood=weeks }\end{array}$ & $\begin{array}{l}\text { Depends on } \\
\text { recapture rate; } \\
\text { positive juveniles } \\
\text { indicate recent } \\
\text { transmission }\end{array}$ & $\mathrm{NO}$ \\
\hline $\begin{array}{l}\text { Dead } \\
\text { Birds }\end{array}$ & NO & $\begin{array}{l}\text { Passive (not } \\
\text { reliable) }\end{array}$ & $\begin{array}{l}\text { Weeks or } \\
\text { longer }\end{array}$ & $\begin{array}{l}\text { A bird infected with } \\
\text { the virus sometime in } \\
\text { the past died at a } \\
\text { particular location }\end{array}$ & $\mathrm{NO}$ \\
\hline Humans & YES & Passive & 4-6 weeks & $\begin{array}{l}\text { Too late for timely } \\
\text { decisions about } \\
\text { mosquito control } \\
\text { opperations; Infected } \\
\text { mosquitoes are } \\
\text { likely, but may not } \\
\text { still be around }\end{array}$ & YES \\
\hline
\end{tabular}

